\title{
How Do Public Officials Perceive Themselves as Taxpayers? A Study of Effect of Modernized Tax Administration System, Tax Sanction, Tax Service, and Tax Morale on Tax Compliance of Public Officials in Indonesia
}

\author{
Abdul Rahman \\ School of Public Administration Bandung \\ National Institute of Public Administration (STIA LAN Bandung) \\ Bandung, Indonesia \\ rhnoke@yahoo.com
}

\begin{abstract}
Low tax compliance in Indonesia constitutes an anomaly conditions if it is referred to the considerable GDP per capita growth and the tax reforms conducted more than three decades. It means that Indonesia still faces with problematic tax compliance influenced by the behavior of public officials. Therefore, this study focused on this group by measuring perceptions of public officials toward their tax compliance and toward factors underlying tax compliance. As a result, although public officials perceived their tax compliance in the good category, in fact, they perceived in the average of bad category for factors underlying their tax compliance. As consequence, the effect of them is however very low. Therefore, to increase Indonesia's tax compliance, it is required strong commitment from public officials as a role model to improve their behaviors.
\end{abstract}

Keywords: tax compliance; public officials; modernized tax administration system; tax sanction; tax service; tax morale

\section{I.INTRODUCTION}

Governments worldwide aim at sustainable high levels of tax compliance, in the sense that they strive for increasing and maintaining tax compliance levels so that their tax ratios are in accordance with international standards, by average in the range of 20-40 percent GDP [1]; [2]. Unfortunately, Indonesia has not succeeded in this context.

As a developing country with high economic growth rates [8] and GDP per capita growth (i.e. that represents the capability of person to pay taxes), Indonesia still has problem with its low tax compliance. It is evidenced by the capability of government to collect taxes or tax ratio at just around 12 percent of GDP. Based on the literature, tax compliance in Indonesia is problematic for four main reasons. Firstly, public trust toward tax authorities is relatively weak because of tax corruption involving tax officials. Secondly, in Indonesia inadequacies in the provision of public goods by the state play an important role. A low level of public provision of goods by the state will affect tax compliance, and thus has implications for tax revenue (which will make it even harder to keep up decent levels of provision). Thirdly, there are still significant problems related to the services and facilities for paying taxes. Discrimination in services, the complexity of using tax applications, unequal service facilities and lack of dissemination are regular features of the Indonesian tax administration. Finally, there is a lack of commitment by government to improve tax compliance by integrating various databases with relevant information [3].
Referring these reasons, Indonesia concerns about tax compliance issue. This is because the existence of it affects tax revenue. Currently, almost 80 percent of government income is derived by tax revenue, so that many efforts are realized by reforms of tax system. Tax reforms in Indonesia are performed in the two phases, in which the first stage is carried out in the interval of 1983 until 2000 by issued the policy to change official assessment with self-assessment, as a system that gives trust to the taxpayer to calculate, report and pay their own tax obligations. Afterward, the reforms are continued by innovations covered formulating a set of more simplicity, neutral, equity and certainty tax regulations, reorganization, enhancing of employee numbers and enlargement of the line procedures. Furthermore, the second phase of reform is began in 2001 by many innovations focused on modernizing tax administration system, improving tax sanction, tax service, and tax morale [4]; [5]; [6]; [7].

Unfortunately, these efforts spending many resources could not be able to solve the problem of poor tax compliance. Until 2014, Indonesia's tax ratio is still about 12 percent. According to the perspective of problematic tax compliance in Indonesia, I found the link between the low tax compliance with the behavior of public official, in which their behaviors are accompanied by two normative assumptions as role model and father-figures for society. Interestingly, to date, there is no research related to tax compliance of public officials. Therefore, I conducted study focused on the role of public officials as taxpayers. In this study, I explored tax compliance of public officials and factors underlying their tax compliance. Based on the review of policy documents and literatures, I highlighted the four important factors that are relevant to tax compliance, namely modernized tax administration system, tax sanction, tax service, and tax morale.

To look at the role of public officials as taxpayers, I design a frame work by combining the concept of tax compliance and four main factors underlying tax compliance by main research question:

"How do public officials in Indonesia perceive their tax compliance being influenced by underlying factors such as the level of modernization of the tax administration system, tax sanctions, tax services and tax morale?"

Corresponding author: Abdul Rahman 


\section{II.RESEARCH METHOD}

In this study, I formulated the framework of study by combining the concept of tax compliance with four main factors that are relevant to tax compliance, namely modernized tax administration system, tax sanction, tax service, and tax morale. The illustration of framework can be show in the following figure:

Figure 1. Research framework

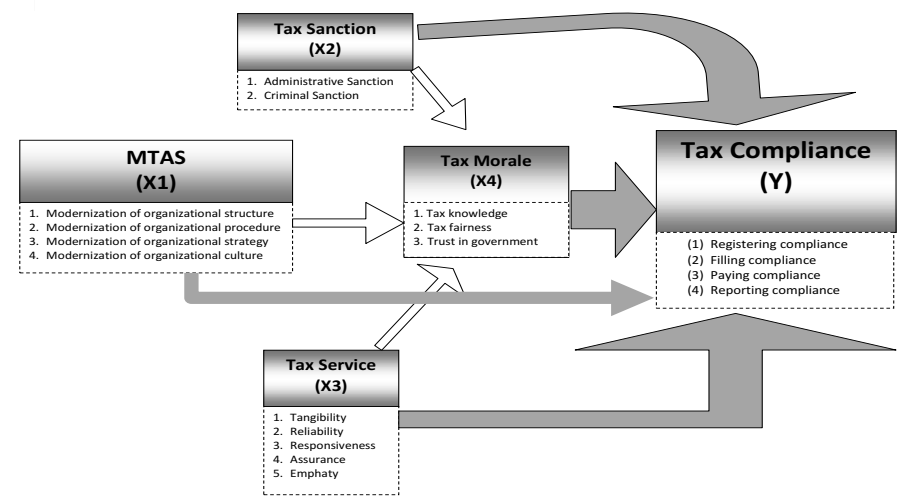

In this framework, I determined the tax compliance as dependent variable and the modernized tax administration system, tax sanction, tax service, and tax morale as independent variables. With this framework, I can measure how these two kinds of variables interacts both partial and combined relationships including direct and indirect relationship and effect for these relationships.

To implement this framework, I generated the survey study with public officials as unit of analysis to explore the perception of them toward their tax compliance and toward factors underlying tax compliance. By knowing their perception, I can describe the behavior of tax compliance of public officials. This is because according to Robbin [5], perception affects a behavior, or in other word, the behavior of a person represents his perception.

As the first step, I conducted sampling to attain the number of respondents of survey study. Because of total population of public officials in Indonesia more than 5 million, then we carried out the sampling based on the formula of Taro Yamane or Slovin [6]. I obtained 400 respondents. Because public officials in Indonesia consist of government employees and state enterprise employees, and by considering this study also explores and compares these two groups, then we apply stratified sampling as second step to attain the proportional sample based on the share of two groups in population by utilizing the formula of Lynch. Moreover, I use questionnaire as a tool to collect data. In this context, data will be collected from the response of respondents toward a set of statements, both positive and negative statements. Furthermore, the questionnaire uses Likert scales. Ideally, a questionnaire provides all potential answers for each statement. It means, by using Likert scale, the answer to be $1=$ strongly disagree, 2 = disagree, $3=$ neutral, $4=$ agree, $5=$ strongly agree, and also the option of 'don't know' (number 8), for respondents who could not answer the question at hand.

In my questionnaire, I started with the ideal model by providing all possible answers for respondents. "Forced choice" to counter the bias from the answer 'neutral' was considered, but was not chosen, as I feared that such forced choice could increase partial non-response (as respondents would then opt for the "don't know" answer or provide no answer at all). As a consequence, I have to anticipate the problem, in which the Likert scale data provide the arbitrary character of the scales because of neutral answers that produces the data are not very telling in terms of description.

To eliminate this flaw, in the part of the analysis, I therefore used an alternative way to aggregate the answers on the various

statements. I looked at the answers of respondents in terms of agreement (i.e. strongly agree and agree) or disagreement (i.e. strongly disagree and disagree) on positively and negatively formulated statements respectively. The number of such answers given by respondents was then divided by the total number of statements (S). In implementation, for example, a score of 40 percent means that for 40 percent of all statements on a specific dimension, the respondent (strongly) agrees with the (positively formulated) statements and/or (strongly) disagrees with the negatively formulated statements (and has chosen other answer possibilities in 60 percent of the cases).

Data collected then are analyzed by descriptive analysis to depict perception of respondents toward their tax compliance and toward factors underlying tax compliance and the verification analysis to measure the effect of perceptions on factors that are relevant to tax compliance toward the tax compliance of respondent by correlation and regression analysis. All analyses are performed by using application of SPSS ver.17.

\section{III.RESULT AND DISCUSSION}

The purpose of this survey study was to investigate how public officials in Indonesia perceive their tax compliance being influenced by underlying factors such as the level of modernization of the tax administration system, tax sanctions, tax services and tax morale. Specifically, the objectives were to understand the effect of the perception by public officials regarding implementation of modernized tax administration system, tax sanction, tax service, and tax morale on their tax compliance and to draw recommendations for further improvements.

The survey study involved 400 respondents, all of them public officials, with 360 government employees and 40 state enterprise employees. Most of the respondents were male and married. The most common age group was 29-39 years old; the most common level of education was a bachelor's degree. Respondents indicated they got their tax knowledge from the internet and through tax socialization (i.e. tax information from tax offices). In terms of origin, the respondents were adequately spread over Indonesia; they come from 29 different provinces. Most respondents were civil servant in local government, and most respondents had income in addition to their salary.

According to descriptive analysis, in which we explore the perception of respondents as taxpayers and the perception toward tax compliance and factors underlying their tax compliance, we highlight the main findings that are shown as follows: 


\section{A. Respondents as Taxpayers}

In this sub-section, we present the findings regarding the role of the respondents as taxpayers in the tax system, by focusing on four aspects: 1) experience of respondents in fulfilling their tax obligations; 2) experience with services in tax offices, 3] the interest in and knowledge of respondents regarding taxation; 4) respondents' perceptions of their position in the implementation of the tax system. This description is meant to provide some background information, before (in section 5.3) we more systematically present findings on respondents' tax compliance and their perception of the importance of the four underlying factors.

\section{B. Experiences in Fulfilling Tax Obligations}

According to our findings, about 31 percent of the respondents do not submit the annual tax return regularly. Specifically, over the last 2 years, around 27 percent indicate that they have been late in submitting the annual tax return; nearly 24 percent of the respondents have been late in paying the personal income tax. However, only about 16 percent of the respondents have experiences with getting tax sanctions. This means that a considerable part of the respondents, who do not submit their tax return on time and/or do not pay their taxes on time, is not confronted with the appropriate sanctions. Out of those respondents that indicated that they have been late in submitting their tax return, 55 percent said they were not confronted with administrative sanctions; 63 percent said that they were not confronted with criminal sanctions. 42 percent of the respondents, who indicated both late submitting and paying were not hit by administrative sanctions; 44 percent of these respondents indicated that no criminal sanctions were taken against them.

\section{Experience with Services in Tax Offices}

About 55 percent of the respondents indicate that over the last three years they have visited the tax office only 1-5 times. About 17 percent indicate more frequent visits (6-10 times or more than 10 times). Around 26 percent of the respondents did not visit the tax office over the last three years. A very small proportion of the respondents (about 1 percent) indicated that they never visit the tax office because their annual tax return is reported via a dropbox.

As far as the purpose of visits is concerned, most of the respondents that indicated one or more visits over the last three years, come to submit the annual personal tax return (mentioned by 79 percent of the respondents), and/or to register the tax identification number (mentioned by almost 76 percent of the respondents), to submit monthly and yearly tax reports (66 percent), to consult (65 percent) or to complain (51 percent). Other reasons include picking up tax dissemination material, tax forms, changing the tax identification number cards, and reporting a change of job status.

Asked for the facilities at their local tax offices, the respondents indicated that the following facilities were present: parking space (mentioned by 95 percent of the respondents), waiting room (96 percent), electronic board or digital signs (83 percent), toilets (94 percent), TV and newspaper (89 percent), electronic queue (82 percent), tax materials and forms (93 percent), a help desk (85 percent), air-conditioning (almost 90 percent), and wifi (44 percent). Other facilities that were mentioned by some respondents include a worship or meditation room and candy for visitors.

Nearly 92 percent of the respondents indicate that all services at their tax offices are free of charge. This is in accordance with government regulations. However, we find that some respondents (8 percent of all respondents) mention that they actually pay money for services at the tax office, either for some administrative services (mentioned in 40 percent of the cases where respondents indicated some sort of payment), and/or consultation fees ( 25 percent), and/or a tip for the service (also 25 percent) and/or costs of negotiations (approximately 23 percent). This illustrates the existence of irregularities in the tax sector.

Around 26 percent of the respondents mention that they have had unpleasant experiences in getting the right tax services; about 59 percent of the respondents indicate they have never had such bad experiences. Bad experiences relate to complex and not straightforward tax administrative processes (mentioned by around 49 percent of those respondents that have bad experiences), and/or discrimination in service provision (46 percent), and/or length of service provision (47 percent), and/or the need to pay for several services ( 37 percent), and/or unfriendly services ( 34 percent), and/or less informative services (51 percent), and/or unresponsive services (49 percent).

Of the respondents, 16 percent mention that they use one or more external parties in handling their tax obligations. These parties consist of private tax consultants (mentioned by 36 percent) and/or staff working in tax offices and providing private consultancy (46 percent) and/or staff in their own office (38 percent) and/or colleagues in their own office (39 percent), and/or corporate treasurers ( 64 percent).

Regarding the experiences of respondents with the interaction with Indonesia's modernized tax administration system, 58 percent of respondents said they have experienced changes in the tax office after introduction of this modernization; 48 percent said they have not experienced any change. Changes highlighted include the application of new information and technology (mentioned by 80 percent of the respondents who experienced changes); the implementation of information systems and technology for tax services specifically (79 percent); more responsible tax officials (70 percent); more ease in determining the wealth imposed taxes (67 percent); shorter lead time for services ( 73 percent); more transparency (67 percent); drastic reduction of the unofficial charges (69 percent); better tax dissemination (66 percent); improvement of standard operating procedures for tax services (72 percent); the use of individual identity in e-fin/e-filling ( 60 percent); the online submission of tax returns to facilitate taxpayers (72 percent); office facilities that are more complete, and "as good as in the bank" (69 percent); quick and comfortable tax services (69 percent); and submitting the annual tax return more flexible, via online or coming directly to the tax offices (approximately 71 percent).

\section{Interest in and Knowledge of Respondents Regarding Taxation}

Asked for the extent to which they were interested in tax matters, only 26 percent of the respondents indicated that they are interested in taxation. Nearly 55 percent was neutral; around 6 
percent of the respondents said that they were uninterested or very uninterested.

This relatively low level of interest is also reflected in the level of knowledge. After a brief explanation of the issues at hand, respondents were asked if they consider themselves to have sufficient understanding/knowledge of issues of tax compliance, modernized tax administration, tax sanctions, tax services, and tax morale. On average only 52 percent of the respondents indicated to have sufficient knowledge of these issues; tax compliance issues are said to be understood sufficiently by 62 percent of the respondents, tax services by 56 percent, tax sanctions by 52 percent, modernized tax administration system by 47 percent, and tax morale issues by 44 percent.

\section{E. Views of respondents regarding the tax system and their role in it}

Asked what first comes to mind when the term taxation is used, 76 percent of the respondents came up with a positive association, such as the importance of taxation for state revenue (about 18 percent), the duty of every citizen with a taxable income to pay taxes (15 percent), the improvement of public facilities (13 percent), economic development (13 percent), welfare for the poor people ( 9 percent) and helping others $(8$ percent). This indicates that most respondents have a positive frame regarding taxation. On the other hand, 24 percent of the respondents associated taxation with negative issues, such as getting sanctions ( 8 percent), reduced income ( 6 percent), audits ( 4 percent), and complexity in tax administrative processes $(5$ percent).

The vast majority of respondents (95 percent) acknowledged that they have the responsibility to pay taxes. Asked more specifically on certain obligations, the respondents agree that this involves having a TIN (98 percent), paying taxes properly and timely (93 percent), filling out and submitting annual tax returns (93 percent), submitting the annual tax return on time (89 percent), conducting the bookkeeping (only 55 percent), reporting other taxable incomes than the basic salary (77 percent), reporting data of tax objects correctly ( 84 percent) and -generally- implementing tax laws properly (88 percent).

Confronted with some specific statements about tax compliance, 78 percent of the respondents said they actively fulfill their tax obligations, 60 percent said they are proud to pay taxes because they feel that the current public facilities are in accordance with the taxes paid, and 71 percent even find themselves happy if their incomes are taxed. According to 79 percent of the respondents, tax laws should be obeyed whatever the conditions. 80 percent agrees that non-compliance in taxation always leads to declining tax revenue. However, 29 percent of the respondents feel that paying taxes is primarily a burden.

In general, only about 34 percent of the respondents are satisfied with the implementation of the tax system in Indonesia. Nearly 26 percent are dissatisfied because they consider the government to have failed in the development of Indonesia (mentioned by 46 percent of these respondents) and/or because of the misuse of tax resources (73 percent). Another factor mentioned (by 42 percent) is the absence of significant changes in the tax system in spite of decades of tax reform and the implementation of a modernized tax administration system. Of all the respondents 64 percent agree with the statement that employees in the public sectors are good in making rules but poor in their realization and/or the apparatus is good in making laws, but in the end they violate them.

Regarding their own role, 72 percent of the respondents agree that employees in the public sectors are part of the implementation of tax laws and are a role model for the society based on the labor law no. 43, article 5, of 1999. Around 76 percent of the respondents are aware that their behavior is an example for the community, especially when it comes to fulfilling tax obligations. 80 percent state that in the end they are proud to be a role model in taxation. Of all respondent's 79 percent agree that tax compliance has to be started from the leaders; the statement that their behaviors are an exemplary model for subordinates, also regarding taxation, is agreed upon by 85 percent of the respondents. In fact, 40 percent of the respondents admit that their own tax compliance behavior follows the tax compliance behavior of their boss(es).

Finally, respondents were asked if they agree (or not) with the main relationships that were part of the analytical framework. On average (for the four relations involved) 80 percent of the respondents agree that the existence of modernized tax administration system, tax sanctions, tax services, and tax morale affects their tax compliance. In more detail, they agree that the modernization of structure, procedure, strategy, and culture within the framework of a modernized tax administration system produces simple administration process and facilitates them in meeting tax obligations ( 85 percent agree); the existence of administrative and criminal sanctions as a tool to educate taxpayers and to create the discipline makes them to be cautious and afraid of making mistakes (82 percent agree); the existence of tax knowledge, tax fairness, and trust in government prompts them to pay taxes and to submit the annual tax return ( 77 percent agrees); and the existence of physical facilities at the tax office, reliability, responsiveness, assurance and empathy from the tax officials facilitate them in the administrative process ( 77 percent agree).

\section{F. Perception toward tax compliance and factors underlying tax compliance}

Figure 1 shows the average perception of public officials of their tax compliance and the underlying factors. Based on the answers to the statements on various elements of tax compliance (register compliance, filing compliance, paying compliance, reporting compliance), public officials generally perceive their tax compliance as good. Still, from answers to other questions in the survey, it became clear that public officials behave far from perfect: over the last two years 27 percent did not submit the annual tax return in time, and nearly 24 percent of the respondents indicated that they had been late in paying the income tax. We tested for differences in perception of tax compliance between various sub-samples (based on gender, age, educational level, and province of origin), but no significant differences were found.

Figure 2. Average perception* of tax compliance and factors influencing it

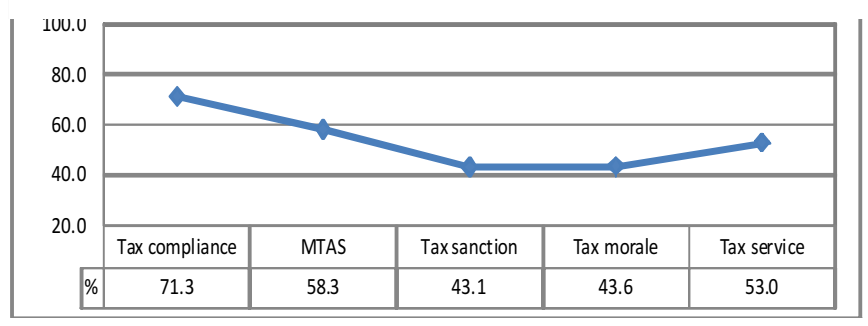

*The perception of respond ents on dimensions based on score interp retation of $20.00-36.00=$ "very bad"; $36.01-52.00=$ "bad"; $52.01-68.00$ = "sufficient"; $68.01-84.00=$ "good"; "84.01-100.00 = "very good" (Narimawati, 2010). 
When we look at the four underlying factors, there is a clear difference between MTAS and tax services on the one hand, and tax sanctions and tax morale on the other hand.

The scores on MTAS and tax services (based on the relevant statements in the survey) are not high, but can be labeled as sufficient. From other questions in the survey it became clear that a large minority (48 percent) of the respondents did not experience much change in the tax administration in terms of modernization; almost one third (26 percent) of the respondents indicated that they have had bad (i.e. discriminatory, unfriendly) experiences with getting the right tax services. A small group of respondents ( 8 percent) mentioned that they had to pay for certain tax services (which are supposed to be free).

The scores on tax sanction and tax morale were rather low (bad perception). As far as tax sanctions are concerned this can be due to the fact that approximately half of those respondents that admitted to have been non-compliant recently, were not hit by any tax sanction. It is also interesting to note that public officials, even though they perceive their tax compliance as good, have a bad perception of their tax morale. This can be linked to their views on the tax system in Indonesia. The majority of respondents indicated the importance of paying taxes, and the vast majority of respondents acknowledged their obligation to be compliant with tax laws, but the survey results also showed considerable dissatisfaction with the way the tax system is implemented in Indonesia. Respondents mentioned the government's failure in properly developing Indonesia, the misuse of tax revenues, failing tax reforms, and the gap between intentions as laid down in tax laws and actual implementation. Still, a large majority acknowledged that as public officials they are role models for other taxpayers.

The verification analysis showed that in terms of the overall model, the four variables (MTAS, tax services, tax morale, and tax sanctions) have a combined effect of 14.6 percent on the dependent variable of tax compliance. Significant (but rather low) correlations with tax compliance were found for MTAS, tax services and tax morale, but not for tax sanctions. The combined effect of MTAS, tax sanctions, tax service, and tax morale has a higher effect on tax compliance of public officials than their partial effects taken together (this is also true for the two subsamples of government employees and state enterprise employees). The main policy implication of this finding is that a limited focus, in terms of future reforms, on just one or two of the four elements is not advisable; a comprehensive approach makes more sense.

Table 1. Comparison between direct and indirect effect (via tax morale) of MTAS, tax sanction and tax services on tax compliance

\begin{tabular}{|c|c|c|}
\hline Kind of Effect & Causal Effect & Percent \\
\hline $\begin{array}{l}\text { MTAS (X1) on } \\
\text { Tax Compliance } \\
(\mathrm{Y})\end{array}$ & $\begin{array}{l}\text { Direct effect } \\
\text { Indirect effect } \\
\text { via tax morale }\end{array}$ & $\begin{array}{l}5.48 \% \\
7.08 \%\end{array}$ \\
\hline $\begin{array}{l}\text { Tax Sanction } \\
(\mathrm{X} 2) \text { on Tax } \\
\text { Compliance }(\mathrm{Y})\end{array}$ & $\begin{array}{l}\text { Direct effect } \\
\text { Indirect effect } \\
\text { via tax morale }\end{array}$ & $\begin{array}{l}0.00 \% \\
0.19 \%\end{array}$ \\
\hline $\begin{array}{l}\text { Tax Service }(\mathrm{X} 3) \\
\text { on } \\
\text { Compliance }(\mathrm{Y})\end{array}$ & $\begin{array}{l}\text { Direct effect } \\
\text { Indirect effect } \\
\text { via tax morale }\end{array}$ & $\begin{array}{l}1.15 \% \\
1.96 \%\end{array}$ \\
\hline
\end{tabular}

The analytical model used for this part of the empirical research, assumed that MTAS, tax services, and tax sanctions have a direct effect on tax compliance, but also an indirect effect through the variable of tax morale. Table 1 shows these direct and indirect effects.

\section{IV.CONCLUSION}

Low tax compliance in Indonesia constitutes an anomaly conditions if it is referred to the considerable GDP per capita growth and the tax reforms conducted more than three decades. Currently, Indonesia still faces with problematic tax compliance influenced by the behavior of public officials. Therefore, I conducted the research focused on this group to explore the role of public officials as taxpayer by considering them as a role model and father-figures for society (normative assumptions) and to date, there is no research related to this issue.

As a result, although public officials perceived their tax compliance in the good category, in fact, they perceived in the average of bad category for factors underlying their tax compliance in which other public officials were as implementer these factors. As consequence, the effect of the four main factors is however very low. These findings indicated the failure of public officials in fulfilling their functions as role models. Although, they perceive in the good category for tax compliance, the bad perception toward the four main factors underlying tax compliance and low effect these factors on tax compliance resulted that the tax compliance of public officials is volatile and is vulnerable to shock and to deviate.

Therefore, the improvements should be conducted related the role of public officials as taxpayers. This study recommends that public officials should be more transparency and publicly declare their incomes. Assessment for them should be done by external auditors and not by colleagues. In the general scope, government should inform transparent information regularly about how tax revenues are used. All attempts to improve the behaviors of public officials as taxpayers require a strong commitment. This commitment is a primary tool because, referring their function as a role model, the positive and negative behavior of public officials as taxpayers can affect the behavior of society in fulfilling tax obligation.

\section{REFERENCES}

[1] J. Andreoni, B. Erard and J.Feinstein. "Tax Compliance," Journal of Economic Literature, Vol. 36 June, 818-860, 1998.

[2] European Commission, "The Annual Report", 2014.

[3] J.Prastowo, "Rasio Pajak Rendah, Utang Makin Menumpuk. Rasio Pajak Negara Miskin Lebih Tinggi dari Indonesia. PRAKARSA Policy Review, 2012

[4] J.Toye, "Fiscal Crisis and Fiscal Reform in Developing Countries. Cambridge Journal of Economices: 24, 21-24, 2000.

[5] S.P. Robbins, "Organizational Behavior Concept, Controversiest, Applications”, 6Ed, Prentice Hall, Inc. Eaglewood, Cliff, New Jersey, 2003.

[6] Riduwan, "Measurement Scale of Research Variables". Bandung: Alfabeta, 2005.

[7] L.M. Sari, “Analisis Dampak Reformasi Pajak 2009 Terhadap Kinerja Pajak di Indonesia". Jurnal Akuntansi Unesa, Vol.1, No.1, 2012.

[8] G.Setiyaji and H. Amir, "Evaluation of Performance of Indonesia's Tax System". Journal of Economy, University of Indonusa Esa Unggul Jakarta, 2005.

[9] J.Brondolo, C. Silvani, E. L. Borgne, and F. Bosch,"Tax Administration Reform and Fiscal Adjustment: The Case of Indonesia (2001-2007). Journal of Economics, 2008. 